\title{
Keragaman dan Intensitas Infeksi Endoparasit Gastrointestinal pada Sapi Bali dengan Sistem Ekstensif di Kabupaten Kupang
}

\section{Diversity and Intensity of Gastrointestinal Endoparasite in Bali Cattle with Extensive System in Kupang District}

\author{
I Gusti Komang Oka Wirawan ${ }^{1 *}$, I Ketut Jaya ${ }^{2}$, Melkianus Dedimus Same Randu² \\ ${ }^{1}$ Program Studi Kesehatan Hewan (Bagian Parasitologi), ${ }^{2} J u r u s a n$ Peternakan, \\ Politeknik Pertanian Negeri Kupang, Jln. Prof. Dr. Herman Yohanes, Kelurahan Lasiana, Kota Kupang \\ PO.BOX 1152 Kupang 85111 \\ *Email: oka_sayun@yahoo.com
}

Naskah diterima: 31 Januari 2019, direvisi: 11 Maret 2019, disetujui: 30 November 2019

\begin{abstract}
Tanah Putih Village is potential for the development of Bali cattle since it has extensive grazing land and the majority of farmers raise Bali cattle. The aim of the study was to obtain data on the diversity and intensity of gastrointestinal endoparasite infection in Bali cattle with an extensive breeding system in Tanah Putih Village, Kupang Timur District, Kupang Regency, East Nusa Tenggara Province. Gastrointestinal endoparasite diversity was identified using sedimentation and flotation methods while the intensity of endoparasite infection was carried out using McMaster method. The diversity and rates of gastrointestinal endoparasite infection were analyzed descriptively. The results of the study on the diversity of gastrointestinal endoparasite showed that there were five types of nematode worm eggs namely Haemonchus contortus, Oesophagostomum radiatum, Strongyloides papillosus, Bunostomum phlebotomum, and Trichostrongylus axei. Factors that support the diversity of endoparasite are feed sources, livestock populations, and grazing rotation. The average number of worm eggs was based on the total eggs per gram of faeces for Haemonchus contortus as many as 100 eggs and the other four types of worm eggs amounted to 50 eggs. The average number of eggs indicates that endoparasite infections in these animals fall into the mild intensity category, which is influenced by season, feed source, and age of livestock. The five types of gastrointestinal endoparasite found namely Haemonchus contortus, Oesophagostomum radiatum, Strongyloides papillosus, Bunostomum phlebotomum, and Trichostrongylus axei.
\end{abstract}

Key words: Bali cattle; gastrointestinal endoparasitic infection

\begin{abstract}
Abstrak
Desa Tanah Putih berpotensi untuk pengembangan sapi Bali karena memiliki padang penggembalaan yang cukup luas dan peternak sudah familiar dengan ternak tersebut. Tujuan penelitian adalah memperoleh data mengenai keragaman dan intensitas infeksi endoparasit gastrointestinal pada sapi Bali dengan sistem pemeliharaan ekstensif di Desa Tanah Putih, Kecamatan Kupang Timur Kabupaten Kupang Provinsi Nusa Tenggara Timur. Identifikasi keragaman endoparasit gastrointestinal menggunakan metode pengendapan dan pengapungan, sedangkan intensitas infeksi endoparasit menggunakan metode McMaster. Data keragaman dan tingkat infeksi endoparasit gastrointestinal dianalisis secara deskriptif. Hasil penelitian mengenai keragaman endoparasit gastrointestinal ditemukan lima jenis telur cacing kelas nematoda, yaitu Haemonchus contortus, Oesophagostomum radiatum, Strongyloides papillosus, Bunostomum phlebotomum, dan Trichostrongylus axei. Faktor yang mendukung keragaman endoparasit ini adalah sumber pakan, populasi ternak, dan rotasi penggembalaan. Rata-rata jumlah telur cacing yang ditemukan berdasarkan total telur per gram feses untuk Haemonchus contortus sebanyak 100 butir, sedangkan keempat jenis telur cacing yang lainnya berjumlah 50 butir. Rataan jumlah telur ini mengindikasikan bahwa infeksi endoparasit pada ternak sapi Bali termasuk dalam kategori intensitas ringan, hal ini dipengaruhi
\end{abstract}


oleh musim, sumber pakan, dan umur ternak. Lima jenis endoparasit gastrointestinal yang ditemukan adalah Haemonchus contortus, Oesophagostomum radiatum, Strongyloides papillosus, Bunostomum phlebotomum, dan Trichostrongylus axei.

Kata kunci: infeksi endoparasit gastrointestinal; sapi Bali

\section{Pendahuluan}

Desa Tanah Putih Kecamatan Kupang Timur Kabupaten Kupang Propinsi Nusa Tenggara Timur mempunyai potensi untuk pengembangan ternak sapi Bali sebagai ternak komoditi karena mempunyai padang penggembalaan yang cukup luas dan peternak di daerah ini sudah familiar memelihara sapi Bali. Berdasarkan Badan Pusat Statistik (2008) melaporkan bahwa Kecamatan Kupang Timur memiliki populasi ternak sapi paling tinggi, yaitu 17.596 ekor dibandingkan 23 kecamatan yang lainnya.

Adapun alasan peternak memilih sapi Bali sebagai ternak komoditi adalah mudah beradaptasi dengan lingkungan yang ekstrim dengan sumber pakan yang terbatas, lebih tahan terhadap penyakit, dan rata-rata menghasilkan pedet setiap tahun sekali. Beberapa kelebihan sapi Bali adalah kemampuan beradaptasinya dalam lingkungan dengan ketersediaan pakan berkualitas rendah tetapi fertilitasnya sangat baik, fertilitas dan persentase karkas tinggi, serta mudah beradaptasi dengan lingkungan (Handiwirawan dan Subandriyo, 2004; Matondang dan Talib, 2015).

Sistem pemeliharaan ternak sapi Bali di Desa Tanah Putih umumnya menerapkan pemeliharaan sistem ekstensif dan hanya beberapa peternak yang menerapkan pemeliharaan sistem intensif yang bertujuan untuk penggemukkan dengan waktu pemeliharaan $2-3$ bulan terhitung dari awal pembelian. Sapi-sapi yang telah mencapai bobot badan minimal $400 \mathrm{~kg}$ kemudian dipasarkan secara lokal atau diantarpulaukan. Manajemen pemeliharaan sistem ekstensif yang dilakukan oleh peternak yaitu ternak dilepas berminggu-minggu bahkan sampai berbulan-bulan di padang penggembalaan sehingga berpeluang terinfeksi endoparasit. Telur cacing yang dikeluarkan bersamaan dengan feses oleh ternak sapi terinfeksi akan menjadi sumber penularan bagi ternak ruminansia yang sehat atau diantara ternak terinfeksi sehingga pengendalian endoparasit gastrointestinal sulit dilakukan.

Kerugian ekonomi akibat infeksi endoparasit gastrointestinal dampaknya belum dirasakan secara langsung oleh peternak karena tidak menimbulkan kematian ternak secara langsung tetapi mempengaruhi asupan nutrisi dan gangguan fisiologi. Kedua faktor ini dapat berpengaruh terhadap penurunan antibodi sehingga ternak lebih peka terhadap penyakit yang lain. Jika kejadian ini berlanjut maka secara ekonomi peternak mengalami kerugian karena peternak membutuhkan waktu yang lebih lama untuk mencapai berat badan tertentu sesuai dengan target yang diinginkan dan peternak mengeluarkan biaya tambahan untuk perawatan ternak yang sakit.

Berdasarkan data Badan Pusat Statistik Kabupaten Kupang (2013) prevalensi helminthiasis pada sapi di dataran Timor Propinsi Nusa Tenggara Timur dari tahun 2010 - 2012 secara berurutan adalah $21,9 \%, 22,3 \%, 44,7 \%$. Data ini masih menggambarkan prevalensi helminthiasis pada sapi secara umum, belum mencerminkan infeksi endoparasit secara spesifik mengenai keragaman endoparasit gastrointestinal pada sapi Bali maupun tingkat infeksinya berdasarkan total telur per gram (TTG) feses. Oleh karena itu diperlukan penelitian mengenai jenis-jenis dan tingkat infeksi endoparasit gastrointestinal pada sapi Bali dengan sistem pemeliharaan ekstensif di desa tersebut.

Tujuan penelitian adalah memperoleh data mengenai keragaman dan intensitas infeksi endoparasit gastrointestinal pada sapi Bali dengan sistem pemeliharaan ekstensif di Desa Tanah Putih Kecamatan Kupang Timur. Manfaat teoritis yang diharapkan, dapat digunakan sebagai sumber data acuan dan pemetaan endoparasit gastrointestinal (epidemiologi eksperimental) pada musim kemarau bagi para akademisi di lingkup Politeknik Pertanian Negeri Kupang serta berkontribusi sebagai sumber informasi bagi pengembangan ilmu pengetahuan dan teknologi. Hasil penelitian ini juga diharapkan dapat digunakan sebagai referensi untuk pengembangan penelitian lanjutan terutama pada musim kemarau di Propinsi Nusa Tenggara Timur.

Manfaat praktis dari penelitian ini adalah dapat digunakan sebagai acuan oleh tenaga medis di dalam melakukan tindakan preventif maupun kuratif, sehingga prevalensi helminthiasis di Desa Tanah Putih Kecamatan Kupang Timur dapat dikendalikan. 


\section{Materi dan Metode}

Materi utama dalam penelitian ini adalah feses segar sebanyak $10 \mathrm{sampel} /$ minggu, pengambilan dilakukan sebanyak 12 minggu pada musim kemarau (April - Juli 2018). Bahan pendukung yang diperlukan adalah formalin $10 \%$ untuk mengawetkan sampel, aquades sebagai pelarut sampel yang digunakan dalam metode sedimentasi, larutan garam jenuh digunakan sebagai media pengapung dalam metode pengapungan dan metode McMaster.

Peralatan yang digunakan meliputi : pot plastik sebagai tempat sampel feses, gelas beker sebagai wadah larutan, kertas tisu untuk mengeringkan preparat, gelas obyek dan gelas penutup (cover glass) sebagai media pemeriksaan sampel, tabung reaksi, rak tabung, saringan teh, spatula sebagai prasarana untuk ketiga metode yang digunakan, dan timbangan elektrik ketelitian 0,001 gram untuk menimbang sampel. Mikroskop stereo (Hirox KH-8700, H08754 made in Japan) untuk pengamatan telur cacing. Kamar hitung (E-Counting Chamber By : $\beta$ ravo, 1080 x 1350) untuk menghitung telur cacing pada metode MacMaster. Sentrifus untuk memisahkan kotoran-kotoran yang ada dalam sampel feses, mortir digunakan untuk menggerus sampel feses.

Prosedur penelitian pemeriksaan sampel feses menggunakan tiga metode yaitu sedimentasi, pengapungan, dan McMaster. Metode sedimentasi ini telah dimodifikasi dan mengacu pada prosedur yang dilakukan oleh Zajac dan Conboy (2012), prosedur : feses diambil sebanyak 3 gram kemudian ditaruh di dalam mortir, ditambah aguades $\pm 5 \mathrm{~mL}$ dan digerus. Hasil gerusan disaring dengan saringan teh dan ditampung pada gelas beker, kemudian hasil saringan ini dimasukkan ke tabung reaksi secara perlahanlahan sampai volumenya $3 / 4$ bagian tabung dan bila volumenya kurang bisa ditambahkan aquades ke dalam tabung sambil diaduk menggunakan spatula hingga homogen. Setelah itu masukan ke dalam alat pemusing (sentrifus), alat pengatur sentrifus ditempatkan pada posisi kecepatan $1.500 \mathrm{rpm}$ selama 2 menit, kemudian tabung diambil dan supernatan dituangkan sehingga hanya tersisa feses yang homogen. Endapan feses diambil menggunakan spatula dari dasar tabung sebesar pentolan korek api dan ditaruh diatas gelas obyek kemudian ditambahkan sedikit aguades untuk memudahkan pembuatan preparat hapus, selanjutnya preparat diperiksa dibawah mikroskop dengan pem- besaran lensa obyektif 350x, untuk memperjelas pengamatan identifikasi morfologi telur cacing maka pembesarannya bisa dirubah ke pembesaran yang lebih kuat. Prinsip dari metode ini menurut Hendrix (206) yang disitasi oleh Demelash et al. (2016) adalah mengendapkan telur cacing di dalam sedimen, terutama digunakan untuk mendeteksi telur cacing yang memiliki berat jenis lebih tinggi dari larutan pengapung. Apabila tidak ditemukan jenis telur cacing dari kelas trematoda maka identifikasi dilanjutkan dengan metode pengapungan.

Metode pengapungan dilakukan dengan cara : setelah dilakukan metode sedimentasi bisa langsung dilanjutkan dengan metode ini dengan cara menambahkan larutan garam jenuh sampai volumenya $3 / 4$ tabung. Kemudian diaduk dan dipusingkan kembali dengan kecepatan yang sama seperti metode sedimentasi dalam waktu 2 menit. Setelah dipusingkan tabung diambil dan diletakkan pada rak tabung dengan posisi tegak lurus, selanjutnya ditambah larutan garam jenuh sampai permukaannya cembung. Kemudian cover gelas disentuhkan pada permukaan larutan, selanjutnya diletakkan diatas obyek gelas dan diperiksa di bawah mikroskop dengan pembesaran lensa obyektif 350x, untuk memperjelas pengamatan identifikasi morfologi telur cacing maka pembesarannya bisa dirubah ke pembesaran yang lebih kuat. Metode pengapungan ini telah dimodifikasi dan mengacu pada prosedur yang dilakukan oleh Zajac dan Conboy (2012). Prinsip dari metode pengapungan menurut Christie et al. (2011) yang disitasi oleh Demelash et al. (2016) adalah pemeriksaan feses, didasarkan pada prinsip bahwa telur parasit yang berat jenis lebih rendah dibandingkan dengan larutan flotasi. Ini adalah metode yang paling optimal karena terjadi pemisahan telur dari kotoran feses dengan mengapungkannya pada berbagai larutan. Identifikasi telur cacing dengan mencocokan telur yang ditemukan dengan kunci identifikasi yang disusun oleh Zajac dan Conboy (2012).

Metode McMaster dilakukan dengan cara : sampel feses digerus kemudian diambil sebanyak 4 gram dicampur dengan larutan pengapung $(\mathrm{NaCl}$ jenuh) sebanyak $56 \mathrm{~mL}$ untuk menghasilkan volume total 60 $\mathrm{mL}$. Selanjutnya disaring menggunakan saringan teh, hasil saringan sebanyak $0,5 \mathrm{~mL}$ dimasukkan ke dalam setiap kamar hitung (Whitlock) menggunakan spuit 1 $\mathrm{mL}$, jika terdapat gelembung udara di dalam kamar hitung maka larutan tersebut dikeluarkan dan diisi kembali. Larutan sampel yang ada di dalam kamar 
hitung dibiarkan minimal selama 5 menit dengan tujuan memberikan kesempatan telur caing berada dipermukaan larutan pengapung. Penghitungan telur cacing pada masing-masing kamarhitung menggunakan mikroskop dengan pembesaran lensa obyektif 350x. Jumlah telur cacing yang ditemukan pada setiap kamar hitung dikalikan 50. Metode telah dimodifikasi dan mengacu pada prosedur yang dilakukan oleh MAFF, 1986 disitasi oleh Lambertz et al. (2018) ; Junaidi et al. (2014). Data mengenai keragaman dan intensitas infeksi endoparasit gastrointestinal ditabulasi serta dianalisis secara deskriptif.

\section{Hasil dan Pembahasan}

Hasil pemeriksaan sampel feses menggunakan metode sedimentasi hanya ditemukan jenis-jenis telur cacing dari kelas nematoda (Tabel 1) oleh karena itu dilanjutkan dengan metode pengapungan. Penyebab tidak ditemukan telur cacing dari kelas cestoda dan trematoda kemungkinan karena kedua kelas dari endoparasit tersebut mempunyai siklus hidup tidak langsung atau memerlukan hospes intermedier sehingga siklus hidupnya lebih komplek, sedangkan cacing dari kelas nematoda mempunyai siklus hidup langsung. Sesuai pendapat Aryandrie et al. (2015) menyatakan bahwa musim hujan dapat memicu infestasi Fasciola $s p$. karena kondisi yang mendukung untuk penyebaran telur cacing melalui siput Lymnaea rubiginosa yang menjadi inang perantara cacing Fasciola sp. Lebih lanjut, Jabbar et al. (2016) menyebutkan bahwa cacing dari kelas cestoda adalah parasit yang memiliki siklus hidup tidak langsung dimana manusia bertindak sebagai inang definitif, sedangkan babi (Taenia solium, Taenia asiatica) dan ternak sapi (Taenia saginata) berfungsi sebagai inang perantara.

Ukuran dan ciri-ciri morfologi telur cacing yang ditemukan dapat dilihat pada Tabel 1 . Ciriciri morfologi telur cacing yang ditemukan sesuai dengan acuan atlas dari Zajac dan Conboy (2012), yang menyatakan bahwa Haemonchus contortus memiliki dinding tipis, terdapat blastomer yang hampir memenuhi ruangan telur, berbentuk elips; Oesophagostomum radiatum memiliki dinding tipis dan terdapat 16 sampai 32 blastomer; Strongyloides papillosus berwarna transparan dan berdinding tipis; Bunostomum phlebotomum memiliki permukaan dinding halus, terdapat 4 sampai 8 blastomer berwarna gelap; dan Trichostrongylus axei berbentuk elips tidak teratur, terdapat 16 sampai 32 blastomer.

Keragaman endoparasit gastrointestinal yang menginfeksi sapi Bali di Desa Tanah Putih didukung oleh tiga faktor, yaitu sumber pakan, populasi ternak, dan rotasi penggembalaan. Interaksi padang penggembalaan yang digunakan secara bersama-sama antara sapi Bali dengan ternak kambing atau ternak ruminansia liar lainnya memberikan peluang yang lebih besar terjadinya kontaminasi sumber pakan (rumputrumputan) oleh larva infektif nematoda tersebut. Hal tersebut dapat mengakibatkan terjadinya infeksi silang secara horizontal diantara ternak-ternak ruminansia di padang penggembalaan (Gambar 1). Sesuai pendapat Candra et al. (2016) menyatakan bahwa di pinggiran kawasan Taman Nasional Way Kambas (TNWK), di lokasi yang bersinggungan antara satwa liar dan ternak domestik ditemukan adanya interaksi infeksi serta penularan penyakit cacing dari satu inang dengan inang yang lainnya, endoparasit yang ditemukan, yaitu : telur cacing Paramphistomum spp, Strongylus spp., dan Strongyloides spp., baik pada satwa liar maupun pada ternak domestik.

\section{Glukosa}

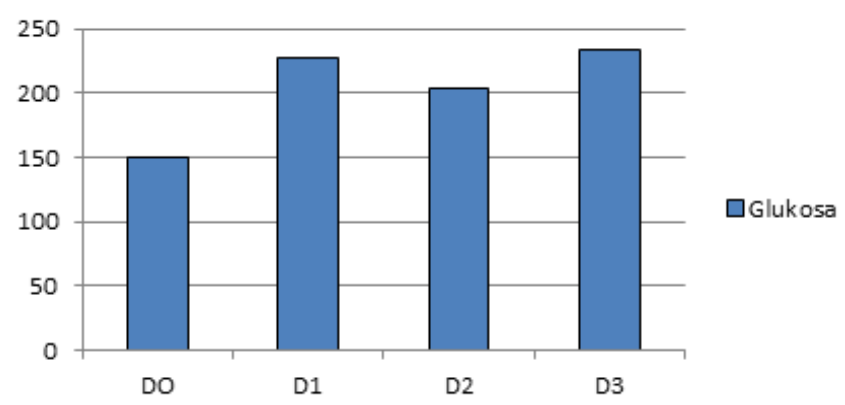

Gambar 1. Interaksi sapi dan kambing di padang penggembalaan

Tabel 1. Keragaman Endoparasit Gastrointestinal

\begin{tabular}{lcc}
\hline \multicolumn{1}{c}{$\begin{array}{c}\text { Keragaman endoparasit } \\
\text { gastrointestinal }\end{array}$} & $\begin{array}{c}\text { Rataan ukuran telur cacing berdasarkan } \\
\text { pengamatan }\end{array}$ & $\begin{array}{c}\text { Acuan ukuran telur cacing (Thienpont } \\
\text { et al. }(1985)\end{array}$ \\
\hline Haemonchus contortus & $88,26 \mu \mathrm{m} \times 48,08 \mu \mathrm{m}$ & $62-95 \mu \mathrm{m} \times 36-50 \mu \mathrm{m}$ \\
Oesophagostomum radiatum & $75,36 \mu \mathrm{m} \times 50,34 \mu \mathrm{m}$ & $75-98 \mu \mathrm{m} \times 46-54 \mu \mathrm{m}$ \\
Strongyloides papillosus & $47,06 \mu \mathrm{m} \times 25,05 \mu \mathrm{m}$ & $47-65 \mu \mathrm{m} \times 25-26 \mu \mathrm{m}$ \\
Bunostomum phlebotomum & $103,75 \mu \mathrm{m} \times 48,75 \mu \mathrm{m}$ & $88-104 \mu \mathrm{m} \times 47-56 \mu \mathrm{m}$ \\
Trichostrongylus axei & $86,35 \mu \mathrm{m} \times 36,20 \mu \mathrm{m}$ & $70-108 \mu \mathrm{m} \times 30-48 \mu \mathrm{m}$ \\
\hline
\end{tabular}


Interaksi antara ternak ruminansia ini juga berpengaruh terhadap peningkatan populasi yang sinergis dengan peningkatan spot-spot feses di daerah padang penggembalaan. Akumulasi feses terutama di daerah padang penggembalaan yang lembab akan mendukung siklus hidup dari nematoda untuk berkembang menjadi larva infektif. Bila diantara ternak-ternak ruminansia ini memakan sumber pakan yang mengandung larva infektif maka ternak yang bersangkutan akan berpeluang terinfeksi. Sesuai pendapat Silvester et al., (2013) mengatakan bahwa kelembaban tinggi dan suhu hangat mendukung perkembangan telur menjadi larva infektif. Lebih lanjut menurut pendapat Asif et al., (2008), penggunaan padang penggembalaan yang sama antara ternak muda dan dewasa serta didukung oleh kondisi lingkungan yang buruk, merupakan kondisi ideal untuk transmisi endoparasit dari satu hospes definitif ke hospes definitif yang lainnya.

Padang penggembalaan dengan sumber pakan berlimpah di lokasi tertentu membuat ternak sapi atau ternak ruminansia lainnya berkumpul dalam suatu kawasan ini dalam kurun waktu yang relatif lama sehingga kontaminasi sumber pakan oleh keragaman larva infektif semakin tinggi. Kondisi padang penggembalaan seperti ini menyebabkan infeksi silang diantara ternak ruminansia tersebut sulit untuk dikendalikan karena terjadi keberlangsungan siklus hidup di luar tubuh hospes definitif secara berkelanjutan. Manajemen pengendalian endoparasit menurut pendapat Kumar et al. (2013) adalah parasitisme akan menurun jika jumlah lahan bertambah dan lebih sering dilakukan rotasi padang penggembalaan. Prinsip dari metode rotasi yaitu ternak akan digembalakan pada lahan yang sama setelah risiko infeksinya berkurang. Lebih lanjut menurut Carmichael et al. (1992) yang disitasi oleh Sani et al. (2004), menyatakan bahwa mengurangi waktu yang dihabiskan hewan di padang rumput dengan meningkatkan frekuensi rotasi maka

Tabel 2. Tingkat Infeksi Keragaman Endoparasit Gastrointestinal

\begin{tabular}{lc}
\hline $\begin{array}{c}\text { Keragaman Endoparasit } \\
\text { Gastrointestinal pada } \\
\text { Sapi Bali }\end{array}$ & $\begin{array}{c}\text { Rataan Intensitas Infeksi } \\
\text { Berdasarkan Total Telur Per } \\
\text { Gram (TTG) Feses (Butir) }\end{array}$ \\
\hline $\begin{array}{l}\text { Haemonchus contortus } \\
\text { Oesophagostomum }\end{array}$ & 100 \\
radiatum & 50 \\
Strongyloides papillosus & 50 \\
Bunostomum & 50 \\
phlebotomum & 50 \\
Trichostrongylus axei & \\
\hline
\end{tabular}

dapat menekan populasi parasit di padang rumput yang berpengaruh terhadap peningkatan produktivitas hewan.

Berdasarkan hasil perhitungan total telur per gram (TTG) feses menggunakan metode McMaster maka infeksi pada sapi Bali di daerah ini termasuk ke dalam kategori intensitas rendah (Tabel 2). Sesuai dengan pendapat Ezenwa (2004) menyatakan bahwa standar tingkat infeksi endoparasit gastrointestinal pada sapi dapat dibagi tiga yaitu infeksi ringan jika jumlah telur $0-500$ butir per gram feses, infeksi sedang: jumlah telur $550-1.500$ butir per gram feses, dan infeksi berat: jumlah telur $\geq 1.550$ butir per gram feses.

Intensitas infeksi endoparasit gastrointestinal pada sapi Bali termasuk dalam kategori rendah keadaan ini dipengaruhi oleh musim, sumber pakan, dan umur ternak. Musim kemarau di Propinsi Nusa Tenggara Timur identik dengan kekeringan karena kondisi geografisnya yang berbukit-bukit kapur sehingga suhu lingkungan menjadi lebih tinggi. Kondisi lingkungan yang seperti ini kurang mendukung perkembangan siklus hidup endoparasit gastrointestinal di luar tubuh hospes definitif yang menyebabkan intensitas infeksinya rendah berpengaruh terhadap penurunan tingkat prevalensi endoparasit di daerah tersebut. Sesuai dengan pendapat Wirawan et al. (2015a) dan Wheeler (2011) menyatakan bahwa lingkungan kawasan dengan suhu panas $\left( \pm 39^{\circ} \mathrm{C}\right)$ dan berbatu kapur sangat berpengaruh terhadap proses perkembangan atau siklus hidup endoparasit gastrointestinal di luar hospes definitif. Lebih lanjut menurut Regassa et al. (2006); Al-Shaibani dan Al-Haj (2010), prevalensi dan tingkat infeksi endoparasit yang lebih tinggi secara signifikan pada musim hujan dibandingkan dengan musim kemarau, hal ini berhubungan langsung dengan kelembaban dan suhu.

\section{Adiponectin}

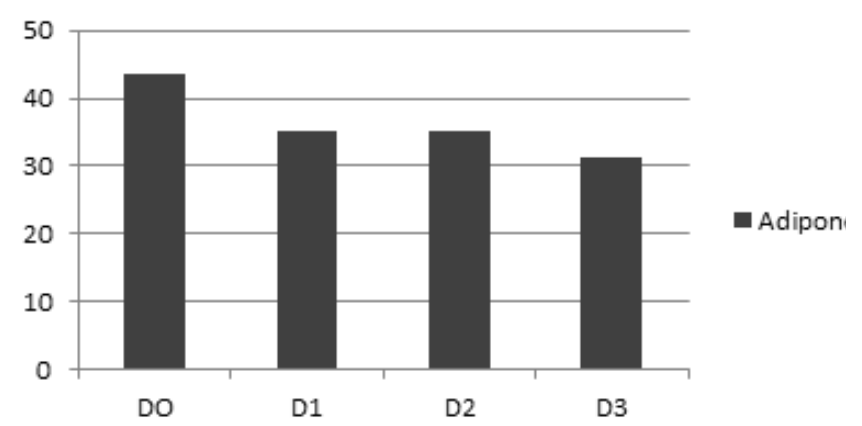

Gambar 2. A. Tumbuhan Leucaena leucocephala, Spondias pinnata. B. Chromolena odorata 
Musim kemarau berpengaruh terhadap terbatasnya sumber pakan di padang penggembalaan terutama rumput lapang sehingga ternak sapi lebih dominan mengkonsumsi daun-daunan atau biji-bijian yang berasal dari tumbuh-tumbuhan liar (Gambar 2A). Perubahan pola pakan ini juga dapat meminimalisir intensitas infeksi endoparasit gastrointestinal pada sapi Bali di wilayah itu karena larva infektif nematoda umumnya berada pada bagian daun dari rerumputan di sekitar sumber pakan. Belum ada laporan penelitian maupun text book yang menyatakan bahwa larva infektif ditransmisikan melalui daun tumbuhtumbuhan. Sesuai dengan pendapat Junquera, (2014); Pugh dan Baird, (2012); Wheeler, (2011) menyatakan bahwa siklus hidup ini spesifik untuk sebagian besar nematoda gastrointestinal (misalnya Teladorsagia, Trichostrongylus, Haemonchus dan Ostertagia). Larva tahap ketiga bermigrasi keluar dari feses ketika tersedia kelembaban yang cukup (hujan, banjir, embun), kemudian tertelan oleh hospes pada saat merumput.

Sumber pakan dari jenis tumbuh-tumbuhan jumlahnya sangat beragam di sekitar padang penggembalaan sehingga ternak sapi dapat lebih selektif untuk memilih sesuai dengan kebutuhannya dan berpengaruh terhadap peningkatan palatabilitasnya. Peningkatan palatabilitas umumnya bersinergis dengan peningkatan score kondisi tubuh akibat adanya perbaikan metabolisme sehingga ternak lebih tahan terhadap berbagai infeksi mikroorganisme maupun endoparasit gastrointestinal. Menurut pendapat Eisa et al. (2017) menyatakan bahwa infeksi parasit gastrointestinal pada domba jika diberikan pakan dengan kandungan energi rendah menyebabkan kinerjanya menjadi sangat menurun dan meningkatkan angka mortalitas. Lebih lanjut menurut pendapat Sangma et al. (2012), berkaitan dengan status gizi dan populasi kawanan, prevalensi telur cacing pada domba secara signifikan $(\mathrm{P}<0,01)$ lebih tinggi pada status gizi yang buruk dan populasi yang lebih banyak.

Selektivitas ternak sapi Bali terhadap tumbuhtumbuhan yang tidak lazim dikonsumsi sesuai dengan nalurinya secara langsung dapat melindungi atau mengobati dirinya sendiri dari infeksi mikroorganisme maupun endoparasit gastrointestinal. Adapun tumbuh-tumbuhan liar yang tumbuh subur di padang penggembalaan dan tidak lazim dikonsumsi oleh ternak tersebut adalah Chromolena odorata (Gambar 2B) dan Calotropis procera. Sesuai dengan pendapat Villalba et al. (2014) menyatakan bahwa ruminansia melalui penginderaannya menunjukkkan perilaku anoreksia sehingga mempunyai kecenderungan mengurangi kejadian parasitisme. Selain itu, ruminansia mengobati diri sendiri terhadap parasit gastrointestinal dengan meningkatkan konsumsi senyawa metabolit sekunder dari tumbuh-tumbuhan.

Salah satu kandungan metabolit sekunder dari daun Chromolena odorata dan kulit buah Calotropis procera yang diekstrak menggunakan pelarut air menurut pendapat Mainasara et al. (2011) dan Prasad et al. (2005) adalah senyawa tanin. Secara farmakodinamik senyawa tanin ini bermanfaat sebagai antelmintik yang bersifat ovisida, larvasida maupun vermisida. Mekanisme kerja senyawa tanin menurut pendapat Athanasiadou et al. (2001) menyatakan bahwa antelmintik ekstrak tumbuhan yang mengandung senyawa tanin mempunyai mekanisme kerja yaitu dengan mengikat protein pada larva dan cacing nematoda gastrointestinal sehingga menghambat perkembangan larva atau menyebabkan kematian cacing tersebut.

Lebih lanjut menurut pendapat Min et al. (2005), senyawa tanin dapat bereaksi secara langsung dengan cacing dewasa dengan melekat pada kulit cacing yang menyebabkan distress pada cacing atau secara tidak langsung dapat meningkatkan nutrisi protein pada kambing dan menaikkan sistem imun. Selanjutnya, senyawa tanin nampaknya mampu menghambat penetasan telur cacing pada feses dan menekan perkembangan larva dengan cara berikatan dengan larva tersebut. Senyawa tanin kondensasi yang terdapat pada ekstrak kulit buah muda Calotropis procera konsentrasi 4,5\% mempunyai aktivitas daya hambat perkembangan telur cacing Haemonchus contortus sebesar 88\% (Wirawan et al., 2015b). Menurut Wirawan et al. (2017a) menyatakan bahwa estrak metanol kulit pohon Alstonia scholaris konsentrasi $2,5 \%$ dengan durasi waktu pemaparan lima jam secara in vitro menyebabkan persentase mortalitas cacing $H$. contortus sebesar $100 \%$.

Jenis tumbuh-tumbuhan sebagai sumber pakan sekaligus berfungsi sebagai antelmintik digunakan oleh para peternak sebagai pagar hidup untuk memisahkan kepemilikan padang penggembalaan satu dengan yang lainnya adalah kedondong hutan (Spondias pinnata) dan lamtoro (Leucaena leucocephala (Lam.). Kedua daun dari tumbuhan tersebut selain berfungsi untuk memperbaiki skor kondisi tubuh ternak, secara langsung juga berpotensi untuk pengendalian 
endoparasit gastrointestinal. Sesuai dengan pendapat Wirawan et al. (2017b), menyatakan bahwa ekstrak metanol daun muda Spondias pinnata secara in vitro pada konsentrasi $4,5 \%$ mempunyai efektivitas daya larvasida terhadap Haemonchus contortus sebesar $100 \%$ tidak berbeda nyata dengan kontrol positif yaitu albendazole $0,055 \%(\mathrm{P}>0,05)$.

Lebih lanjut menurut pendapat Ariani et al. (2015), uji aktivitas vermisidal ekstrak etanol biji lamtoro secara in vitro pada konsentrasi $1 \% \mathrm{~b} / \mathrm{v} ; 2 \%$ $\mathrm{b} / \mathrm{v}$; dan $4 \% \mathrm{~b} / \mathrm{v}$ dapat menyebabkan kematian cacing Ascaris suum Goeze secara bermakna dibandingkan dengan kontrol negatif $(\mathrm{P}<0,05)$. Berdasarkan analisis probit ekstrak etanol biji lamtoro memiliki nilai LC100 sebesar 4,24\% b/v dan nilai LT100 sebesar 34,7 jam. Sedangkan uji aktivitas vermisidal ekstrak etanol daun lamtoro secara in vitro menurut Devi et al. (2015), konsentrasi $0,5 \% \mathrm{~b} / \mathrm{v} ; 1 \% \mathrm{~b} / \mathrm{v} ; 2 \% \mathrm{~b} / \mathrm{v}$ dan $4 \% \mathrm{~b} / \mathrm{v}$ mempunyai aktivitas vermisidal secara bermakna apabila dibandingkan dengan kontrol negatif ( $\mathrm{P}$ $<0,05$ ). Berdasarkan analisis probit ekstrak etanol daun lamtoro memiliki nila LC100 sebesar 4,14\%b/v dan nilai LT100 sebesar 39,24 jam.

Umur ternak sapi pada sistem pemeliharaan ekstensif lebih dominan ternak dewasa atau berumur lebih dari tiga tahun sehingga titer antibodinya lebih tinggi dibandingkan ternak muda (pedet) yang menyebabkan ternak dewasa tersebut lebih tahan terhadap infeksi endoparasit. Sesuai dengan pendapat Nabi et al. (2014) menyatakan bahwa epidemologi nematoda gastrointestinal pada ternak kambing ditemukan lima jenis telur cacing, yaitu Nematodirus spathiger, Haemonchus contortus, Trichostrongylus colubriformis, Strongyloides papillosus dan Trichuris ovis. Prevalensi tertinggi dan jumlah telur rata-rata per gram (EPG) faeces ditemukan pada hewan muda $(\leq 1$ tahun) dibandingkan dengan ternak dewasa $(\mathrm{P}<0,05)$. Lebih lanjut menurut pendapat Lashari et al. (2015), prevalensi Haemonchus contortus tertinggi yaitu $31,66 \%$ ditemukan pada kelompok umur 3-12 bulan dan kelompok terendah $>42$ bulan prevalensinya $15,55 \%$.

\section{Kesimpulan}

Disimpulkan bahwa keragaman endoparasit gastrointestinal yang menginfeksi sapi Bali dapat diidentifikasi sebanyak lima jenis, yaitu Haemonchus contortus, Oesophagostomum radiatum, Strongyloides papillosus, Bunostomum phlebotomum, dan Trichostrongylus axei. Infeksi endoparasit gastrointestinal yang menginfeksi sapi Bali dari kelima jenis telur cacing tersebut termasuk dalam kategori intensitas ringan.

\section{Ucapan Terima Kasih}

Penulis mengucapkan terima kasih kepada Direktur dan Kepala P2M Politeknik Pertanian Negeri Kupang yang telah memberikan dana penelitian melalui DIPA Politeknik Pertanian Negeri Kupang Sesuai Dengan Surat Perjanjian Kerja (SPK) Penelitian Nomor: $\quad$ 01/P2M/DIPA.042.01.2.401014/Pol/2018 Tanggal 07 Mei 2018 Pusat Penelitian dan Pengabdian Pada Masyarakat Politeknik Pertanian Negeri Kupang.

\section{Daftar Pustaka}

Al-Shaibani, I.R., dan Al-Haj, A. (2010). Prevalenc Of Gastrointestinal Helminthes In Sheep In And Around Thamar City, Yemen. Yemeni Journal Biol. Science. 6(2): 99-107.

Ariani, N.K.M., Astuti, K.W., dan Yadnya-Putra, A.A.G.R. (2015). Uji Aktivitas Vermisidal Ekstrak Etanol Biji Lamtoro (Leucaena leucocephala (Lam.) de Wit) Pada Cacing Gelang Babi (Ascaris suum Goeze) Secara In Vitro. Jurnal Farmasi Udayana. 4(1): 33-37.

Aryandrie, D.F., Santosa, P.E., dan Suharyati, S. (2015). Tingkat Infestasi Pada Cacing Hati Pada Sapi Bali Di Kecamatan Sukoharjo Kabupaten Pringsewu Provinsi Lampung. Jurnal Ilmiah Peternakan Terpadu. 3(3): 134 - 139.

Asif, M., Azeem, S., Asif, S., dan Nazir, S. (2008). Prevalence of Gastrointestinal Parasites of Sheep and Goats in and around Rawalpindi and Islamabad, Pakistan. Journal Vet Animal Science. Vol 1: 14-17.

Athanasiadou, S., Kyriazakis, I., Jackson, F., dan Coop, R.L. (2001). Direct anthelmintic effects of condensed tannins towards different gastrointestinal nematodes of sheep: in vitro and in vivo studies. Veterinary Parasitology. 99(3): 205-219.

Badan Pusat Statistik (BPS) Kabupaten Kupang. Kupang Dalam Angka. (2008). Kerjasama Pemerintah Kabupaten Kupang Dengan BPS Propinsi Nusa Tenggara Timur. 
Badan Pusat Statistik (BPS) Kabupaten Kupang. Kupang Dalam Angka. (2013). Kerjasama Pemerintah Kabupaten Kupang Dengan BPS Propinsi Nusa Tenggara Timur.

Candra, D., Warganegara, E., Bakri, S., dan Setiawan, A. (2016). Identifikasi Kecacingan pada Satwa Liar dan Ternak Domestik di Taman Nasional Way Kambas, Lampung. Acta Veterinaria Indonesiana. 4(2): 57-67.

Demelash, K., Abebaw, M., Negash, A., Alene, B., Zemene, M., dan Tilahun, M. (2016). A Review on Diagnostic Techniques in Veterinary Helminthlogy. Nature and Science. 14(7): 109 -118 .

Devi, P.K.S., Astuti, K.W., dan Yadnya-Putra, A.A.G.R. (2015). Uji Aktivitas Vermisidal Ekstrak Etanol Daun Lamtoro (Leucaena leucocephala (Lam.) de Wit) Pada Cacing Gelang Babi (Ascaris suum Goeze) Secara In Vitro. Jurnal Farmasi Udayana. 4(1): 83-86.

Eisa, N.Z., Babiker, S.A., dan Abdalla, H.S. (2017). Effect of Natural Gastrointestinal Parasitic Infection on Fattening Performance of Sudan Desert Sheep. Journal of Animal Sciences and Livestock Production. 1(1): 1-6.

Ezenwa, V.O. (2003). Interactions among host diet, nutritional status and gastrointestinal parasite infection in wild bovids. International Journal for Parasitology. 34(2004): 535-542.

Handiwirawan, E., dan Subandriyo. (2004). Potensi Dan Keragaman Sumberdaya Genetik Sapi Bali. Wartazoa. 14(3): 107-115.

Jabbar, A., Gauci, C., dan Lightowlers, M.W. (2016). Diagnosis of human taeniasis. Faculty of Veterinary and Agricultural Sciences, The University of Melbourne, Werribee, Vic. 3030, Australia. Page. $43-45$.

Junaidi, M., Sambodo, P., dan Nurhayati, D. (2014). Prevalensi Nematoda pada Sapi Bali di Kabupaten Manokwari. Jurnal Sain Veteriner. 32(2): $168-176$.

Junquera, P. (2014). Haemonchus spp., Parasitic Roundworms of Cattle, Sheep and Goats. Biology, Prevention and Control.Haemonchus contortus, Haemonchus placei. parasitipedia. net/index.
Kumar, N., Rao, T.K.S., Varghese, A., dan Rathor, V.S. (2013). Internal parasite management in grazing livestock. Journal of Parasitic Diseases. 37(2):151-157.

Lambertz, C., Poulopoulou, I., Wuthijaree, K., dan Gauly, M. (2018). Endoparasitic infections and prevention measures in sheep and goats under mountain farming conditions in Northern Italy. Small Ruminant Research. 164: 94-101

Lashari, M.H., Tasawar, Z., Akhtar, M.S., Chaudhary, M.S., dan Sial, N. (2015). Prevalence of Haemonchus contortus In Local Goats of D. G. Khan. World Journal of Pharmacy and Pharmaceutical Sciences. 4(5): 190-196.

Mainasara, M.M., Aliero, B. L., Aliero, A. A., dan Dahiru, S. S. (2011). Phytochemical and Antibacterial Properties of Calotropis Procera (Ait) R. Br. (Sodom Apple) Fruit and Bark Extracts. International Journal of Modern Botany. 1(1): 8-11.

Matondang, R.H., dan Talib, C. (2015). Model Pengembangan Sapi Bali dalam Usaha Integrasi di Perkebunan Kelapa Sawit. WARTAZOA. 25(3): 147-157.

Min, B. R., Hart, S.P., Miller, D., Tomita, G.M., Loetz, E., dan Sahlu, T. (2005). The effect of grazing forage containing condensed tannins on gastro-intestinal parasite infection and milk composition in Angora does. Journal Vet Parasitol. 130: 105-113.

Nabi, H., Saeed, K., Shah, S.H., Rashid, M.I., Akbar, H., dan Shehzad, W. (2014. Epidimiological Study of Gastrointestinal Nematodes of Goats In District Swat, Khyber Pakhtunkhwa, Pakistan. Science International (Lahore). 26(1): 283-286.

Prasad, S., Narayana, K., Jayakumar, K., dan Srikanth, K.G. (2005). Phytochemical Analysis of Toxic Plant Chromolaena odorata (Eupatorium odoratum). Journal of the Indian Society of Toxicolgy. 1: 1.

Pugh, D.G., dan Baird, A.N. (2012). Sheep and Goat Medicine. Second Edition. Saunders, an imprint of Elsevier Inc. ISBN: 9781437723533.

Regassa, F., Sori, T., Dhuguma, R., dan Kiros, Y. (2006). Epidemiology of Gastrointestinal Parasites of Ruminants in Western Oromia, 
Ethiopia. Internatinal Journal Applied Research in Veterinary Medicine. 4(1): 51-57.

Sangma, A., Begum, N., Roy, B.C., dan Gani, M.O. (2012). Prevalence of helminth parasites in sheep (Ovis aries) in Tangail district, Bangladesh. Journal of Bangladesh Agricultural University. 10(2): 235-244.

Sani, R.A., Gray, G.D., dan Baker, R.L. 2004. Worm Control for Small Ruminants in Tropical Asia. (C) Australian Centre for International Agricultural Research GPO Box 1571, Canberra, Australia 2601.

Silvestre, R-C., Camalig, Fe.M., dan Juliana, Q. (2013). Prevalence of ectoparasites and endoparasites of carabao in Region I. E-International Research Journal. 5(3): 2094-1749.

Villalba, J.J., Miller, J., Ungar, E.D., Landau, S.Y., dan Glendinning, J. (2014). Ruminant selfmedication against gastrointestinal nematodes: evidence, mechanism, and origins. published by EDP Sciences. DOI: 10.1051/parasite/2014032. Page: 1-10.

Wheeler, K. (2011). Impact of grazing management on cattle and sheep parasites. ADAS UK Ltd. Page: 5.
Wirawan, I.G.K.O., Kusumaningrum, D., dan Oematan, A.B. (2015). Keragaman Endoparasit Gastrointestinal pada Macaca fascicularis di Taman Wisata Goa Monyet Tenau, Kota Kupang. Jurnal Sain Veteriner. 33(1): $94-102$.

Wirawan, I.G.K.O., Nurcahyo, W., Prastowo, J., dan Kurniasih. (2015). Daya Ovicidal Ekstrak Kulit Buah Muda (Calotropis procera) terhadap Haemonchus contortus secara in vitro. Jurnal Sain Veteriner. 33(2): $167-173$.

Wirawan, I.G.K.O., Nurcahyo, W., Prastowo, J., dan Kurniasih. (2017). Daya Vermisidal Ekstrak Lima Jenis Etnofarmakologi terhadap Cacing Haemonchus contortus secara In-vitro. Jurnal Sain Veteriner. 35(2): 243 - 253.

Wirawan, I.G.K.O., Nurcahyo, W., Prastowo, J., dan Kurniasih. (2017). Daya Larvasida Ekstrak Daun Muda Kedondong Hutan terhadap Haemonchus contortus secara in vitro. Jurnal Veteruner. 18(2): 283-288.

Zajac, A.M., dan Conboy, G.A. (2012). Veterinary Clinical Parasitology. $8^{\text {th }}$ Edition. American Association of Veterinary Parasitologists. ${ }^{\circledR}$ Iowa State University Press. 